\title{
STUDIES WITH BRUCELLA ENDOTOXIN IN HUMANS: THE SIGNIFICANCE OF SUSCEPTIBILITY TO ENDOTOXIN IN THE PATHOGENESIS OF BRUCELLOSIS
}

\author{
By ROBERT S. ABERNATHY 1 AND WESLEY W. SPINK \\ (From the Department of Medicine, University of Minnesota Medical School, \\ Minneapolis, Minn.)
}

(Submitted for publication August 24, 1957; accepted October 3, 1957)

The mechanisms by which patients ill with brucellosis develop their characteristic symptoms of fever, chills, myalgia, asthenia and malaise have not been precisely elucidated. In particular, the contributions of the brucella cell itself to the pathogenesis of these clinical features have not been extensively investigated. An unusual clinical observation (1) suggested that some component of the cell did play a significant role. When patients seriously ill with brucellosis due to Brucella melitensis were treated with chlortetracycline, an unexpected abrupt febrile response often occurred within 8 to 12 hours after the initial dose of the antibiotic. These adverse reactions could be abolished or ameliorated by administering smaller initial doses of the antibiotic. Such effects suggested to the observers that, as a result of the antibrucella activity of the chlortetracycline, brucella cells were killed, thus liberating some cellular component which then produced the febrile response. This component was presumably the endotoxin of the cell.

That brucellae contain endotoxin has been amply demonstrated by several observers (2-5). This endotoxin, just as that from many other gramnegative microorganisms, consists of lipopolysaccharide-protein complexes located on the surface of the bacterium. It represents not only a toxic component of the cell but also the somatic or " $O$ " antigen. The properties of brucella endotoxin have been extensively studied in the experimental animal (6-8) and have been found to be quite similar to those of endotoxins from other organisms (9). Of particular interest are the observations $(3,10)$ that endotoxins extracted from various strains of the three brucella species have identical toxic and immunologic actions, regardless of the capacity of the individual strain to establish

1 Present address: Department of Medicine, University of Arkansas Medical Center, Little Rock, Ark. infection. In man, the injection of endotoxins from various enteric microorganisms causes fever, headache, chilliness, myalgia, emesis, leukopenia, alterations in carbohydrate metabolism, and vasomotor disturbances which may culminate in shock if sufficient endotoxin is given $(11,12)$. Morgan and Neva $(13,14)$ observed such reactions in subjects given typhoid and paratyphoid endotoxins. Because of the similarity of these reactions to the symptoms of patients with typhoid and paratyphoid fever, it was postulated that endotoxin played a significant role in the pathogenesis of illness in these diseases.

The purpose of the present investigation was to study the role of endotoxin in the pathogenesis of illness in human brucellosis. This was done by observing the reactions of human subjects to the intravenous injection of brucella endotoxin. Such studies have not been previously reported.

\section{MATERIAL AND METHODS}

Endotoxin was extracted from $B r$. melitensis by a modified Boivin procedure (15). In all human tests, the same lot of endotoxin was used. The preparation was a saline suspension containing 0.5 per cent phenol and was stored at $4^{\circ} \mathrm{C}$. over a period of three years. No deterioration or contamination occurred. In humans, endotoxin was given intravenously; the response was measured by observing the systemic reactions of each individual and by recording body temperature orally at one or two hour intervals, beginning one hour prior to challenge and continuing for at least eight hours after challenge or thereafter until the temperature returned to the base line. All patients tested had normal temperatures for at least 48 hours previously; no salicylates were administered during the test period. Fever, as a response to endotoxin, was defined as temperature over $100^{\circ} \mathrm{F}$. In order to compare the individual reactions objectively, the febrile response was quantitated in terms of fever units (14), a value obtained by multiplying the degrees of fever above $100^{\circ} \mathrm{F}$. times the duration of fever in hours. In practice, this was done by plotting each individual temperature response on graph paper con- 
TABLE I

Classification of patients given brucella endotoxin

\begin{tabular}{|c|c|c|c|c|}
\hline $\begin{array}{l}\text { Classification } \\
\text { of groups }\end{array}$ & $\begin{array}{c}\text { Number } \\
\text { of } \\
\text { patients }\end{array}$ & $\begin{array}{l}\text { Brucella } \\
\text { skin } \\
\text { test }\end{array}$ & $\begin{array}{c}\text { Serum } \\
\text { brucella } \\
\text { agglutinins }\end{array}$ & $\begin{array}{c}\text { History } \\
\text { of active } \\
\text { disease }\end{array}$ \\
\hline $\begin{array}{l}\text { Control } \\
\text { Inactive disease } \\
\text { Active disease }\end{array}$ & $\begin{array}{r}16 \\
12 \\
13\end{array}$ & $\begin{array}{l}\text { negative } \\
\text { positive } \\
\text { positive }\end{array}$ & $\begin{array}{l}\text { absent } \\
\leq 1: 80 \\
>1: 80\end{array}$ & $\begin{array}{l}\text { absent } \\
\text { absent } \\
\text { present }\end{array}$ \\
\hline
\end{tabular}

taining 400 small squares per square inch, using the following scales: along the abscissa 1 inch equals 12 hours, and along the ordinate 1 inch equals $2^{\circ} \mathrm{F}$. Each individual square thus represented 0.06 fever unit. The total number of fever units was determined by counting the number of small squares enclosed within the area of the temperature above $100^{\circ} \mathrm{F}$.

The subjects given endotoxin were all hospitalized patients. Three categories of subjects were chosen, the classification of each patient being based upon the following: history of an active disease compatible with brucellosis; serum brucella agglutinin titers; cultures for brucellae; and intradermal reactions to brucella skin test antigens [either the nucleoprotein brucellergin or the detergent-extracted protein antigen of Benedict and Elberg ${ }^{2}$ (16) ]. The essential distinguishing characteristics of each group are presented in Table I. The 13 individuals designated as having active brucellosis consisted predominantly of patients hospitalized for treatment of acute or subacute brucellosis. Included also in this group were three subjects who had apparently recovered completely from a previous acute brucellosis and two individuals with chronic brucellosis, characterized by a significant exposure to brucellae associated with recurrent febrile episodes and high serum brucella agglutinins at some stage of their illness. All of the patients in this category had demonstrated either positive cultures for brucellae or significant agglutinins ( $>1: 160)$ and possessed dermal hypersensitivity for brucella antigens. For comparison, a second group was composed of 12 patients who demonstrated brucella dermal hypersensitivity but gave no history suggesting active brucellosis (either past or present) and had low or absent serum agglutinins. These were selected as individuals with an apparently inactive or subclinical brucella infection. A final control group consisted of 16 patients with no evidence of brucella infection at any time; they all had absent brucella agglutinins and no dermal reactions to brucella antigen. The last two groups were patients initially hospitalized with various illnesses but were apparently similar save for the dermal hypersensitivity; none of the patients were seriously ill at any time.

To investigate the development of resistance to endotoxin activity during human brucellosis, the capacity of serum from patients with brucellosis to protect against the lethality of endotoxin was measured in mice. Male $\mathrm{ABC}$ mice, weighing approximately 20 grams each, were

\footnotetext{
2 Kindly supplied by Dr. S. S. Elberg.
}

used; they were housed 5 to 10 per cage in an airconditioned room, with free access to tap water and Fox Chow. All injections were given intraperitoneally. The amount of endotoxin used for challenge was routinely a $1.5 \mathrm{LD}_{50}$ amount; by weight this varied from 0.9 to $1.2 \mathrm{mg}$., depending on the potency of the individual preparation. When the protective effect of human serum was tested, the serum and endotoxin were mixed together and then injected.

Serum precipitins for brucella endotoxin were determined by a capillary tube technique. Endotoxin, in a concentration of $1 \mathrm{mg}$. per $\mathrm{ml}$. of saline, was drawn into a capillary tube, after which an equal volume of serum was drawn in. The tube was placed in a strip of plasticene embedded in a wooden block, then incubated initially at $37^{\circ} \mathrm{C}$. for 1 hour, and finally kept at $4^{\circ} \mathrm{C}$. for approximately 18 hours. The majority of sera tested had been stored in the frozen state for varying intervals up to five years.

\section{EXPERIMENTAL RESULTS}

\section{A. Occurrence of endotoxin antibodies in bru- cellosis}

Serologic evidence that exposure to the endotoxic component of the brucella cell occurs during the course of human brucellosis was sought by performing precipitin reactions for endotoxin and also by determining the protective capacity of such sera against the lethality of brucella endotoxin for mice.

Precipitins. The sera of 43 patients with active brucellosis were tested for precipitins, a total of 49 sera being tested. Of the 43 patients, 19 gave positive precipitin reactions at some stage of their illness. In Table II, the precipitin reactions are correlated with the duration of clinical disease, a time interval measured from the onset of symptoms. It is seen that precipitins may appear quite early, persist some 6 months, and then begin to decline by 9 to 12 months. When the precipitins were compared with the brucella agglutinin titers

TABLE II

Correlation of precipitin reaction with duration of brucellosis

\begin{tabular}{lccc}
\hline \hline $\begin{array}{c}\text { Duration of } \\
\text { disease }\end{array}$ & $\begin{array}{c}\text { Number } \\
\text { sera } \\
\text { tested }\end{array}$ & $\begin{array}{c}\text { Number } \\
\text { sera } \\
\text { positive }\end{array}$ & $\begin{array}{c}\text { Per cent } \\
\text { positive }\end{array}$ \\
\hline 1-2 weeks & 17 & 7 & $41 \%$ \\
3-4 weeks & 7 & 3 & $43 \%$ \\
2-4 months & 8 & 5 & $63 \%$ \\
5-6 months & 6 & 3 & $50 \%$ \\
9-12 months & 4 & 1 & $25 \%$ \\
$2-12$ years & 6 & 0 & $0 \%$ \\
\hline
\end{tabular}


TABLE III

Correlation of serum precipitin reactions with serum agglutinin titers in human brucellosis

\begin{tabular}{ccc}
\hline \hline \multirow{2}{*}{$\begin{array}{c}\text { Serum } \\
\text { agglutinin } \\
\text { titer }\end{array}$} & \multicolumn{2}{c}{ Serum precipitin reaction } \\
\cline { 2 - 3 } & $\begin{array}{c}\text { Number } \\
\text { positive }\end{array}$ & $\begin{array}{c}\text { Number } \\
\text { negative }\end{array}$ \\
\hline 0 & 0 & 2 \\
$1: 80$ & 0 & 1 \\
$1: 320$ & 1 & 3 \\
$1: 640$ & 3 & 9 \\
$1: 1,280$ & 3 & 7 \\
$1: 2,560$ & 5 & 4 \\
$1: 5,120$ & 6 & 1 \\
$1: 10,240$ & 2 & 1 \\
$1: 20,480$ & 1 & 0 \\
\hline
\end{tabular}

of the same sera (see Table III), it was observed that of those sera with an agglutinin titer of $1: 2,560$ or greater, 70 per cent gave positive precipitin reactions, while in contrast only 24 per cent of those sera with lower agglutinin titers had precipitins.

Passive protection of mice against endotoxin. Sera from 19 patients with brucellosis were tested for their capacity to protect mice against the lethality of brucella endotoxin. Preliminary tests with serum from Patient M. W. indicated that $0.4 \mathrm{ml}$. serum protected mice, whereas $0.2 \mathrm{ml}$. did not. Accordingly, the protective activity of individual sera was tested by challenging mice with a mixture of a lethal dose of endotoxin and either 0.3 or $0.4 \mathrm{ml}$. serum, depending upon the amount available. Sera from five normal individuals were similarly tested, while a control group of mice received only endotoxin. The results are given in Table IV. Since the number of animals for each serum was so small, only those sera protecting at least four of five mice were designated as offering protection. While none of the control normal sera protected mice, nine of the brucellosis sera (or 47 per cent) did give protection. All of these nine sera were found to contain precipitins for the endotoxin; however, three of five sera giving no protection also contained precipitins. Of the 11 sera with agglutinin titers of $1: 1,280$ or less, only 3 (27 per cent) afforded protection; in contrast, of the 7 sera with agglutinin titers of $1: 2,560$ or higher, 5 (72 per cent) gave protection.

\section{B. Reactions to brucella endotoxin in humans}

The responses to intravenous injections of brucella endotoxin were observed in 41 individuals

TABLE IV

Effect of human immune serum on brucella endotoxin lethality in mice

\begin{tabular}{|c|c|c|c|c|c|}
\hline Patient & $\begin{array}{c}\text { Duration of } \\
\text { disease }\end{array}$ & $\begin{array}{l}\text { Precipitin } \\
\text { reaction }\end{array}$ & $\underset{\text { titer }}{\text { Agglutinin }}$ & $\begin{array}{l}\text { Amount } \\
\text { serum } \\
\text { given }\end{array}$ & $\begin{array}{l}\text { Endotoxin } \\
\text { mortality* }\end{array}$ \\
\hline $\begin{array}{l}\text { W. L. } \\
\text { J. R. } \\
\text { J. D. } \\
\text { A. S. } \\
\text { F. S. } \\
\text { J. H. } \\
\text { B. S. } \\
\text { A. B. } \\
\text { J. A. } \\
\text { S. D. } \\
\text { R. P. } \\
\text { L. S. } \\
\text { C. K. } \\
\text { P. A. } \\
\text { H. H. } \\
\text { K. E. } \\
\text { M. W. } \\
\text { R. D. } \\
\text { F. H. } \\
\text { Control } 1 \\
\text { Control } 2 \\
\text { Control } 3 \\
\text { Control } 4 \\
\text { Control } 5 \\
\text { Saline }\end{array}$ & $\begin{array}{c}3 \text { weeks } \\
3 \text { weeks } \\
3 \text { weeks } \\
5 \text { weeks } \\
6 \text { weeks } \\
6 \text { weeks } \\
2 \text { months } \\
2 \text { months } \\
2 \text { months } \\
3 \text { months } \\
4 \text { months } \\
6 \text { months } \\
6 \text { months } \\
6 \text { months } \\
14 \text { months } \\
3 \text { years } \\
1 \text { month } \\
6 \text { months }\end{array}$ & $\begin{array}{c}+ \\
+++ \\
++t \\
+ \\
+ \\
\\
0 \\
+ \\
+ \\
+ \\
++ \\
+++ \\
++ \\
\\
++ \\
0 \\
0 \\
0 \\
0 \\
0\end{array}$ & $\begin{array}{l}1: 320 \\
1: 2,560 \\
1: 2,560 \\
1: 5,120 \\
1: 10,240 \\
1: 1,280 \\
1: 640 \\
1: 1,280 \\
1: 1,280 \\
1: 640 \\
1: 1,280 \\
1: 10,240 \\
1: 5,120 \\
1: 640 \\
1: 160 \\
1: 320 \\
1: 5,120 \\
1: 320 \\
0 \\
0 \\
0 \\
0\end{array}$ & 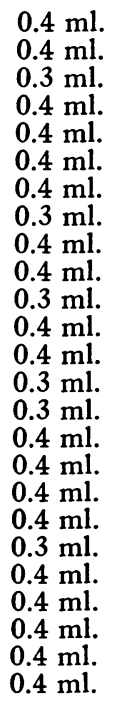 & $\begin{array}{c}5 / 5 \\
2 / 4 \\
3 / 5 \\
1 / 5 \\
0 / 5 \\
1 / 5 \\
5 / 5 \\
5 / 5 \\
2 / 5 \\
2 / 5 \\
1 / 5 \\
0 / 5 \\
0 / 5 \\
0 / 5 \\
3 / 5 \\
2 / 5 \\
0 / 5 \\
2 / 10 \\
5 / 5 \\
4 / 5 \\
3 / 5 \\
7 / 10 \\
10 / 10 \\
5 / 5 \\
33 / 37\end{array}$ \\
\hline
\end{tabular}

* Number dying/number challenged. 
who were divided into three groups as described under the section Material and Methods. In order to determine if differences in suceptibility to endotoxin existed among the three groups, varying amounts of endotoxin were given to the individuals in each group. The data showing the responses in each group are detailed in Table $\mathrm{V}$ for the active group, in Table VI for the apparent inactive group, and in Table VII for the control group.

Systemic response to endotoxin. The systemic response to the intravenous injection of endotoxin characteristically included headache, chilliness or rigors, malaise, and myalgia -all prominent symptoms in brucellosis. Since these subjective com- plaints could not be measured in any precise quantitative fashion, the magnitude of the response was estimated as minimal, moderate or marked. The reactions in each group have been summarized in Table VIII. In the control group, 15 individuals received either 50 or $100 \gamma$ endotoxin and experienced no or minimal reactions save for one person with a moderate reaction. The remaining control patient suffered a moderate reaction when given $250 \gamma$ endotoxin. Patients with inactive or subclinical infection were given amounts of endotoxin ranging from 1 to $100 \gamma ; 7$ of the 12 gave no or minimal reactions, while 5 gave moderate or marked responses. The responses of the group with active brucellosis were

TABLE V

Response to brucella endotoxin in patients with active brucellosis

\begin{tabular}{|c|c|c|c|c|c|c|c|c|c|c|}
\hline & \multirow[b]{2}{*}{$\begin{array}{c}\text { Stage of } \\
\text { brucellosis }\end{array}$} & \multirow[b]{2}{*}{$\begin{array}{l}\text { Duration } \\
\text { of illness }\end{array}$} & \multirow[b]{2}{*}{$\underset{\text { test }}{\text { Skin }}$} & \multirow[b]{2}{*}{$\begin{array}{c}\text { Aggluti- } \\
\text { nins }\end{array}$} & \multirow[b]{2}{*}{$\begin{array}{c}\text { Precipi- } \\
\text { tins }\end{array}$} & \multirow[b]{2}{*}{$\begin{array}{l}\text { Amount of } \\
\text { endotoxin }\end{array}$} & \multicolumn{3}{|c|}{ Febrile reaction } & \multirow[b]{2}{*}{$\begin{array}{l}\text { Systemic } \\
\text { reaction }\end{array}$} \\
\hline $\begin{array}{l}\text { Patient } \\
\text { Age Sex }\end{array}$ & & & & & & & $\begin{array}{l}\text { Time of } \\
\text { onset }\end{array}$ & Duration & $\begin{array}{l}\text { Fever } \\
\text { units }\end{array}$ & \\
\hline $19^{\mathrm{M} . \mathrm{O} .} \mathrm{M}$ & Acute & 5 months & ++ & $1: 5,120$ & ++ & $10 \gamma$ & 5 hrs. & $11 \mathrm{hrs}$. & 6.8 & Marked \\
\hline $31^{\text {E.S. }} M$ & Chronic & 6 years & ++ & $1: 320$ & 0 & $10 \gamma$ & & & 0 & None \\
\hline $45^{R . M}$ & Healed & 2 years & ++ & 0 & 0 & $10 \gamma$ & $10 \mathrm{hrs}$. & $15 \mathrm{hrs}$. & 5.3 & Moderate \\
\hline $28^{\mathrm{W} \cdot \mathrm{J} \cdot}{ }_{\mathrm{M}}$ & Acute & 6 months & ++ & $1: 640$ & 0 & $25 \gamma$ & 2 hrs. & $45 \mathrm{hrs}$ & 77.6 & Marked \\
\hline $22^{\text {F.S. }}$ & Acute & 2 months & + & $1: 2,560$ & + & $25 \gamma$ & $1.8 \mathrm{hrs}$. & $15 \mathrm{hrs}$. & 5.9 & Moderate \\
\hline $38^{\text {S. D. }} M$ & Acute & 3 months & ++ & $1: 640$ & + & $25 \gamma$ & 4 hrs. & 30 hrs. & 61.5 & Marked \\
\hline${ }_{25}{ }_{M}^{\mathrm{J} . \mathrm{H} .}$ & Acute & 7 weeks & + & $1: 10,240$ & & $25 \gamma$ & $3.6 \mathrm{hrs}$. & $6 \mathrm{hrs}$. & 11.2 & Moderate \\
\hline $54^{\text {D. L. }} \mathrm{M}$ & Subacute & 8 months & ++ & $1: 320$ & $\mathbf{0}$ & $25 \gamma$ & 12 hrs.* & " $10 \mathrm{hrs.}^{*}$ & $13.4^{*}$ & Moderate* \\
\hline $46_{M}^{\mathrm{L} . \mathrm{Ba}}$ & Healed & 6 years & ++ & 0 & 0 & $25 \gamma$ & 7 hrs.* & " 30 hrs.* & $36.5^{*}$ & Marked* \\
\hline $36^{\mathrm{J} \cdot \mathrm{R} .} \mathrm{M}$ & Acute & 1 month & +++ & $1: 5,120$ & +++ & $50 \gamma$ & $2 \mathrm{hrs}$. & 33 hrs.* & * $13.0^{*}$ & Marked* \\
\hline $27^{\text {S. N. }}$ & Healed & 4 years & - & $1: 80$ & 0 & $250 \gamma$ & $0.5 \mathrm{hrs}$. & 42 hrs. * & $61.7^{*}$ & Marked* \\
\hline${ }_{26}{ }^{\mathrm{J} \cdot \mathrm{A} .} \mathrm{M}$ & Acute & 2 months & +++ & $1: 1,280$ & + & $\begin{array}{l}1 \gamma(\text { Day } 1) \\
5 \gamma(\text { Day } 3)\end{array}$ & $2 \mathrm{hrs}$. & $5 \mathrm{hrs}$. & $\begin{array}{l}0 \\
0.9\end{array}$ & $\begin{array}{l}\text { None } \\
\text { Minimal }\end{array}$ \\
\hline $59^{\mathrm{S} . \mathrm{T}}{ }_{\mathrm{F}}$ & Chronic & 12 years & ++ & 0 & 0 & $\begin{array}{r}5 \gamma(\text { Day } 1) \\
10 \gamma(\text { Day } 2) \\
20 \gamma(\text { Day } 5) \\
30 \gamma(\text { Day } 9)\end{array}$ & $\begin{array}{r}5 \mathrm{hrs} . \\
2.5 \mathrm{hrs} \text {. } \\
10.8 \mathrm{hrs} \text {. }\end{array}$ & $\begin{array}{l}12 \mathrm{hrs} . \\
12 \mathrm{hrs} . \\
1.2 \mathrm{hrs} .\end{array}$ & $\begin{array}{r}0 \\
3.2 \\
10.3 \\
0.2\end{array}$ & $\begin{array}{l}\text { None } \\
\text { Moderate } \\
\text { Moderate } \\
\text { None }\end{array}$ \\
\hline
\end{tabular}

* Given steroid treatment. 
TABLE VI

Response to brucella endotoxin in patients with inactive brucellosis

\begin{tabular}{|c|c|c|c|c|c|c|c|c|c|}
\hline \multirow[b]{2}{*}{$\begin{array}{l}\text { Patient } \\
\text { Age } \quad \text { Sex }\end{array}$} & \multirow[b]{2}{*}{ Clinical diagnosis } & \multirow[b]{2}{*}{$\underset{\text { test }}{\text { Skin }}$} & \multirow[b]{2}{*}{$\begin{array}{l}\text { Aggluti- } \\
\text { nins }\end{array}$} & \multirow[b]{2}{*}{$\begin{array}{c}\text { Precipi- } \\
\text { tins }\end{array}$} & \multirow[b]{2}{*}{$\begin{array}{l}\text { Amount of } \\
\text { endotoxin }\end{array}$} & \multicolumn{3}{|c|}{ Febrile reaction } & \multirow[b]{2}{*}{$\begin{array}{l}\text { Systemic } \\
\text { reaction }\end{array}$} \\
\hline & & & & & & $\begin{array}{c}\text { Time of } \\
\text { onset }\end{array}$ & Duration & $\begin{array}{l}\text { Fever } \\
\text { units }\end{array}$ & \\
\hline${ }_{51}{ }^{\text {P. B. }} \mathrm{M}$ & No disease & $++t+$ & $1: 80$ & $\mathbf{0}$ & $1 \gamma$ & & & 0 & Moderate \\
\hline $22^{\text {T. R. }} \mathrm{F}$ & Rheumatic fever & ++++ & $1: 80$ & + & $1 \gamma$ & $10 \mathrm{hrs}$. & $30 \mathrm{hrs}$. & 60 & Marked \\
\hline${ }_{56}{ }^{\mathrm{R} . \mathrm{T}}{ }_{\mathrm{M}}$ & Polyneuritis & $++t$ & $1: 40$ & & $5 \gamma$ & & & 0 & None \\
\hline $44^{\mathrm{M} . \mathrm{T}}$ F & Arthritis & + & $1: 20$ & 0 & $10 \gamma$ & $1 \mathrm{hr}$. & $2 \mathrm{hrs}$. & 1.4 & Moderate \\
\hline $54_{F}^{\text {A. A. }}$ & Tuberculosis & +++ & 0 & + & $10 \gamma$ & $6 \mathrm{hrs}$. & $23 \mathrm{hrs}$. & 63.8 & Moderate \\
\hline $46^{M . H}$ F & Renal abscess & + & 0 & 0 & $50 \gamma$ & $1.5 \mathrm{hrs}$. & $2 \mathrm{hrs}$. & 2 & Minimal \\
\hline${ }_{73}{ }^{\mathrm{W} . \mathrm{K}}{ }_{\mathrm{M}}$ & Anemia & + & $1: 40$ & 0 & $50 \gamma$ & $12 \mathrm{hrs}$. & $14 \mathrm{hrs}$. & 9.2 & None \\
\hline $43^{\text {H. U. }}$ F & CA rectum & + & 0 & $\mathbf{0}$ & $50 \gamma$ & & & 0 & None \\
\hline $67^{\text {L. B. }} \mathrm{M}$ & CA esophagus & + & & & $50 \gamma$ & & & 0 & None \\
\hline $31^{\text {R.A. }}{ }_{M}$ & No disease & + & $1: 40$ & & $50 \gamma$ & & & $\mathbf{0}$ & Minimal \\
\hline $54^{\mathrm{V} . \mathrm{H} .} \mathrm{M}$ & Duodenal ulcer & + & $1: 40$ & $\mathbf{0}$ & $100 \gamma$ & $2 \mathrm{hrs}$. & 24 hrs. & 21 & Marked \\
\hline${ }_{41}^{C . K .} \mathrm{F}$ & Neurosis & ++ & $1: 20$ & 0 & $\begin{array}{l}10 \gamma(\text { Day } 1) \\
20 \gamma(\text { Day } 4) \\
40 \gamma(\text { Day } 8)\end{array}$ & $\begin{array}{r}15 \mathrm{hrs} . \\
1.5 \mathrm{hrs} . \\
4 \mathrm{hrs} .\end{array}$ & $\begin{array}{l}8 \text { hrs. } \\
9 \text { hrs. } \\
4 \text { hrs. }\end{array}$ & $\begin{array}{l}1.5 \\
8.9 \\
1.6\end{array}$ & $\begin{array}{l}\text { Moderate } \\
\text { Moderate } \\
\text { Minimal }\end{array}$ \\
\hline
\end{tabular}

TABLE VII

Response to brucella endotoxin in control patients

\begin{tabular}{|c|c|c|c|c|c|c|}
\hline \multirow[b]{2}{*}{ Patient } & \multirow[b]{2}{*}{ Age } & \multirow[b]{2}{*}{ Sex } & \multirow[b]{2}{*}{ Clinical diagnosis } & \multirow[b]{2}{*}{$\begin{array}{l}\text { Amount of } \\
\text { endotoxin }\end{array}$} & \multicolumn{2}{|c|}{ Reaction to endotoxin } \\
\hline & & & & & $\begin{array}{l}\text { Fever } \\
\text { units }\end{array}$ & Systemic \\
\hline $\begin{array}{l}\text { G. S. } \\
\text { E. M. } \\
\text { L. I. } \\
\text { F. B. } \\
\text { J. O. } \\
\text { O. H. } \\
\text { P. G. } \\
\text { W. S. } \\
\text { C. A. } \\
\text { G. Ko. } \\
\text { E. H. . } \\
\text { J. M. } \\
\text { G. Ke. } \\
\text { J. D. } \\
\text { M. F. } \\
\text { H. M. }\end{array}$ & $\begin{array}{l}56 \\
39 \\
70 \\
64 \\
36 \\
62 \\
47 \\
55 \\
21 \\
49 \\
83 \\
76 \\
40 \\
56 \\
61 \\
53\end{array}$ & $\begin{array}{l}\mathbf{M} \\
\mathbf{M} \\
\mathbf{F} \\
\mathbf{M} \\
\mathbf{F} \\
\mathbf{M} \\
\mathbf{M} \\
\mathbf{M} \\
\mathbf{F} \\
\mathbf{M} \\
\mathbf{M} \\
\mathbf{M} \\
\mathbf{M} \\
\mathbf{F} \\
\mathbf{M} \\
\mathbf{M}\end{array}$ & $\begin{array}{l}\text { Duodenal ulcer } \\
\text { Pneumonia } \\
\text { CA breast } \\
\text { Leukemia } \\
\text { Pneumonia } \\
\text { Arthritis } \\
\text { Diabetes; cellulitis } \\
\text { Parkinsonism } \\
\text { Hepatitis } \\
\text { Acute alcoholism } \\
\text { Duodenal ulcer } \\
\text { Pulmonary infarct } \\
\text { Thrombophlebitis } \\
\text { Duodenal ulcer } \\
\text { Asthma } \\
\text { Sarcoidosis }\end{array}$ & $\begin{array}{c}50 \gamma \\
50 \gamma \\
50 \gamma \\
50 \gamma \\
50 \gamma \\
50 \gamma \\
50 \gamma \\
50 \gamma \\
100 \gamma \\
100 \gamma \\
100 \gamma \\
100 \gamma \\
100 \gamma \\
100 \gamma \\
100 \gamma \\
250 \gamma(\text { Day } 1) \\
250 \gamma(\text { Day 2) }\end{array}$ & $\begin{array}{l}0 \\
0 \\
0.3 \\
0 \\
0 \\
0 \\
0 \\
0 \\
0 \\
0 \\
0 \\
0 \\
0 \\
0 \\
0 \\
10.9 \\
12.3\end{array}$ & $\begin{array}{l}\text { None } \\
\text { Minimal } \\
\text { Minimal } \\
\text { Moderate } \\
\text { Minimal } \\
\text { None } \\
\text { None } \\
\text { None } \\
\text { None } \\
\text { Minimal } \\
\text { None } \\
\text { None } \\
\text { None } \\
\text { None } \\
\text { None } \\
\text { Moderate } \\
\text { Moderate }\end{array}$ \\
\hline
\end{tabular}


TABLE VIII

Summary of reactions to endotoxin in humans

\begin{tabular}{|c|c|c|c|c|c|c|c|c|}
\hline \multirow[b]{2}{*}{$\begin{array}{l}\text { Classification } \\
\text { of groups }\end{array}$} & \multicolumn{4}{|c|}{ Number of patients with symptoms } & \multicolumn{4}{|c|}{ Number of patients with fever } \\
\hline & None & Minimal & Moderate & Severe & None & $\begin{array}{l}\text { Minimal } \\
\leq 2 \text { F.U. }\end{array}$ & $\begin{array}{l}\text { Moderate } \\
\text { 5-15 F.U. }\end{array}$ & $\begin{array}{c}\text { Severe } \\
>20 \mathrm{~F} . \mathrm{U}\end{array}$ \\
\hline $\begin{array}{l}\text { Controls } \\
\text { Inactive disease } \\
\text { Active disease }\end{array}$ & $\begin{array}{r}10 \\
4 \\
1\end{array}$ & $\begin{array}{l}4 \\
3 \\
1\end{array}$ & $\begin{array}{l}2 \\
3 \\
5\end{array}$ & $\begin{array}{l}0 \\
2 \\
6\end{array}$ & $\begin{array}{r}15 \\
5 \\
1\end{array}$ & $\begin{array}{l}0 \\
2 \\
1\end{array}$ & $\begin{array}{l}1 \\
2 \\
7\end{array}$ & $\begin{array}{l}0 \\
3 \\
4\end{array}$ \\
\hline
\end{tabular}

almost uniformly more severe than the other groups. Twelve of these individuals were challenged with 1 to $50 \gamma$ endotoxin, while the remaining patient received $250 \gamma$. Only 2 patients experienced no or minimal reactions, while in contrast 11 gave moderate or marked reactions. These results show clearly that those individuals with active brucellosis possess an increased susceptibility to the systemic effects of endotoxin.

Febrile response to endotoxin. The febrile reactions in the three groups have been summarized in Table VIII. Those control individuals receiving 50 or $100 \gamma$ had no febrile reactions; however, when challenged with $250 \gamma$, fever did result. The subjects with inactive infection were less resistant; five of them experienced significant febrile responses to smaller amounts of endotoxin. In contrast, the patients who had active brucellosis were much more susceptible, since all but 2 of the 13 individuals suffered prominent febrile reactions.

Responses characteristic of each group are illustrated in Figure 1, which presents the reactions of three patients to $50 \gamma$ endotoxin. G. S., a control patient, had no febrile or systemic reaction. M. H., an individual whose only evidence of bru- cella infection was a positive skin test, experienced only a slight but distinct response. In contrast, Patient J. R., who was convalescing from acute brucellosis, suffered a marked febrile and systemic response.

This variation in susceptibility is shown in greater detail by correlating the individual febrile responses with the amount of endotoxin given (see Figure 2). For the sake of clarity, the responses of the control group have been omitted from the figure; if shown, the reactions to 50 or $100 \gamma$ would all be clustered at 0 fever units. The increased susceptibility to endotoxin in the other two groups is indicated by the significant febrile responses to 10,25 , or $50 \gamma$ endotoxin, amounts without effect in controls. An analysis of Figure 2 shows that the responses fell into three broad categories: minimal reactions below 2 fever units, moderate reactions of 5 to 15 fever units, and severe reactions greater than 20 units. Individuals with minimal reactions were predominantly those with inactive infections. In contrast, moderate reactors were predominantly patients with active brucellosis. Severe reactions occurred equally in both groups. This apparent

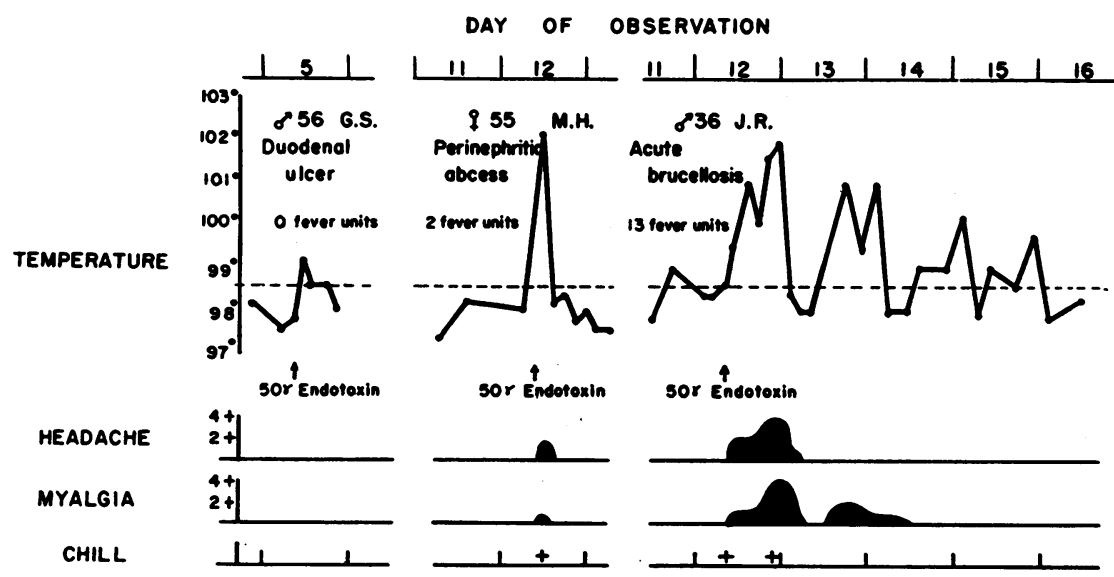

Fig. 1. Typical Responses of Humans to Brucella Endotoxin 


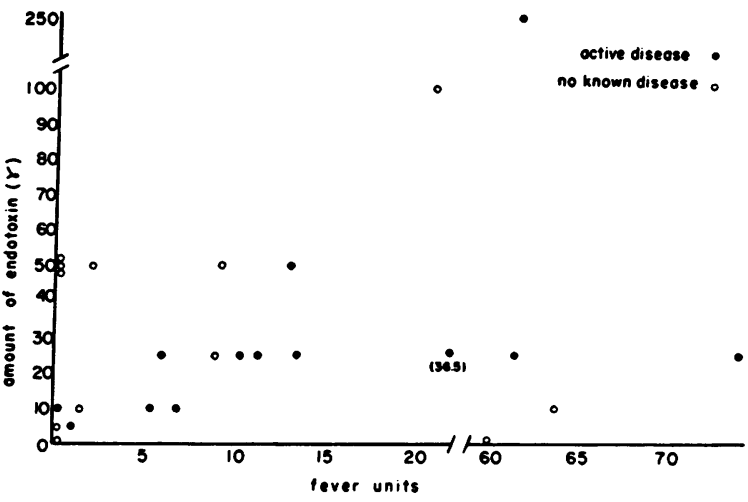

Fig. 2. Febrile Response to Brucella Endotoxin

discrepancy may best be explained by the observation that the two patients with inactive infection experiencing severe reactions both possessed marked dermal hypersensitivity; this point will be further discussed shortly.

It was observed that a latent period occurred between the injection of endotoxin and the onset of the febrile response. The duration of this latent period, the duration of the entire febrile reaction, and the number of fever units were compared in the group with active disease and in the subclinically infected group. Table IX presents a summary of data abstracted from Tables $\mathrm{V}$ and VI, giving the mean value with standard deviation and ranges. Those patients with active brucellosis had a distinctly shorter latent period and a somewhat more prolonged duration of the febrile response. No correlation was found between the amount of endotoxin given and the duration of either the latent period or the febrile response.

Factors influencing the intensity of the response to endotoxin. When the responses of the various individuals were analyzed, it was seen that two factors seemed to influence greatly the individual reaction to endotoxin. The first, as stressed in the preceding discussion, was the occurrence of an active infection. The other important factor was the degree of dermal hypersensitivity to brucella skin test antigens.

The increased susceptibility in patients who had active disease was apparent even in individuals possessing equal dermal hypersensitivity, as illustrated in Figure 3, which contrasts the responses to $25 \gamma$ endotoxin in two patients with skin tests of moderate ( 2 plus) intensity. Patient W. J., who was recovering from acute brucellosis, experienced a severe reaction; on the other hand, Patient C. K., with an inapparent infection, had only a moderate reaction. It was also observed that the increased susceptibility persisted long after apparent complete recovery, for intervals of two to six years (see Table V, Patients R. M., S. N., and L. Ba.).

Correlation of the febrile responses to endotoxin with the degree of dermal hypersensitivity (Table $\mathrm{X}$ ) indicated that in several instances those patients with marked dermal hypersensitvity gave much more severe reactions to the same amount of endotoxin than did patients with a low degree of dermal hypersensitivity. An example of this is presented in Figure 4, which shows the reactions of two patients with inactive infection to the injection of $10 \gamma$ endotoxin. Patient M. T., with only a 1 plus skin test, suffered little reaction, but Patient A. A., who had a 3 plus skin test, experienced a severe reaction.

Development of tolerance to endotoxin. Six individuals were given two or more injections of endotoxin at various intervals. As detailed in Table XI, resistance to the febrile and systemic actions of endotoxin developed in three subjects. This tolerance was not demonstrated in those patients receiving a second injection within five days but was observed in the three individuals given endotoxin six days or more after the initial challenge.

TABLE IX

Comparison of febrile responses to endotoxin in humans with active and inactive brucellosis

\begin{tabular}{cccc}
\hline \multicolumn{1}{c}{$\begin{array}{c}\text { Classification } \\
\text { of group }\end{array}$} & $\begin{array}{c}\text { Time of onset } \\
\text { of reaction }\end{array}$ & $\begin{array}{c}\text { Duration of } \\
\text { reaction }\end{array}$ & Fever units \\
\hline Active disease & $\begin{array}{c}3.3 \pm 0.9 \mathrm{hrs} . \\
(0.5-10 \mathrm{hrs} .)\end{array}$ & $\begin{array}{c}20.5 \pm 3.7 \mathrm{hrs} . \\
(5-45 \mathrm{hrs})\end{array}$ & $\begin{array}{c}14.4 \pm 7.2 \\
(0-78)\end{array}$ \\
Inactive disease & $\begin{array}{c}6.1 \pm 1.9 \mathrm{hrs} . \\
(1-15 \mathrm{hrs} .)\end{array}$ & $\begin{array}{c}14.0 \pm 4.0 \mathrm{hrs} . \\
(2-30 \mathrm{hrs} .)\end{array}$ & $\begin{array}{c}12.9 \pm 5.7 \\
(0-64)\end{array}$ \\
\hline
\end{tabular}




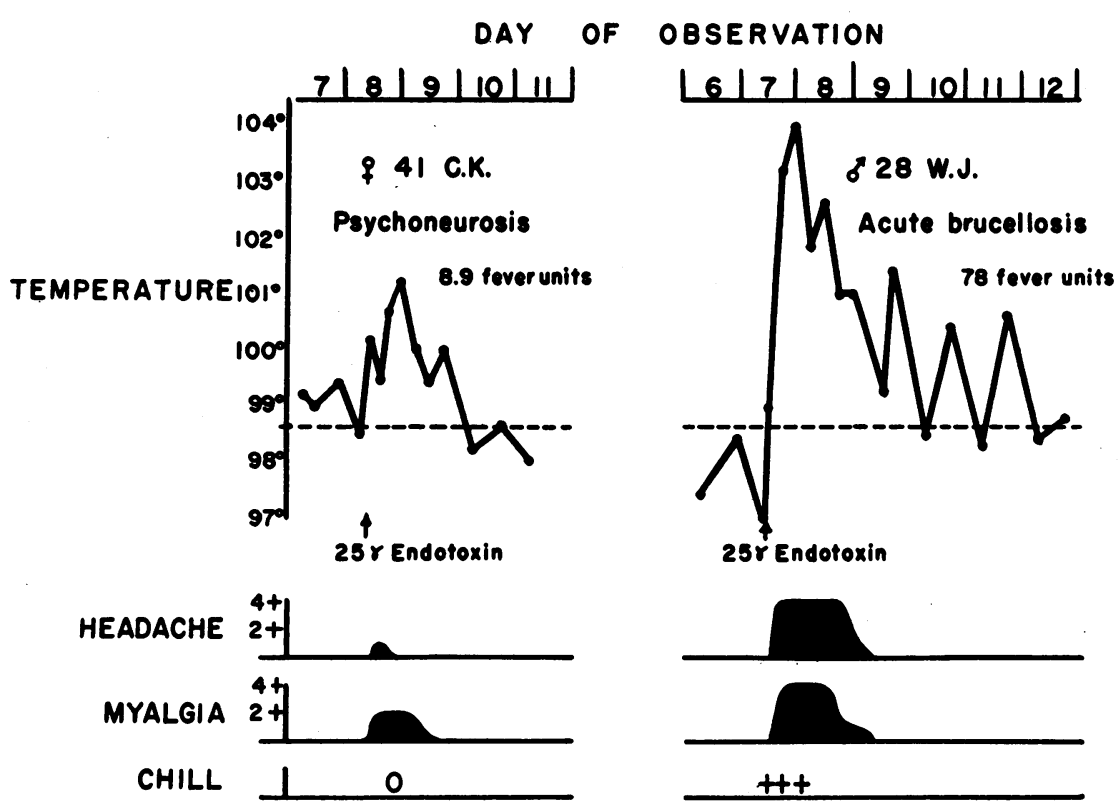

Fig. 3. Effect of Activity of Disease on Reaction to Endotoxin

It may be noted that tolerance appeared not only after repeated injections of endotoxin (Patients S. T. and C. K.) but also after a single injection (Patient J. H.).
Effect of adrenocorticosteroids and adrenocorticotropic hormone on response to endotoxin. Five patients with active brucellosis were given either hydrocortisone or adrenocorticotropic hor-

TABLE $\mathbf{X}$

Correlation of dermal hypersensitivity and febrile response to endotoxin in human brucellosis

\begin{tabular}{|c|c|c|c|c|c|c|c|}
\hline \multirow{3}{*}{$\begin{array}{l}\text { Amount of } \\
\text { endotoxin }\end{array}$} & \multicolumn{7}{|c|}{ Individual reactions to endotoxin (fever units) } \\
\hline & \multicolumn{2}{|c|}{+} & \multicolumn{2}{|c|}{++} & \multicolumn{2}{|c|}{+++} & \multirow{2}{*}{$\frac{++++}{\text { Inactive }}$} \\
\hline & Active & Inactive & Active & Inactive & Active & Inactive & \\
\hline $1 \gamma$ & & & & & & & $\begin{array}{r}0 \\
60\end{array}$ \\
\hline $5 \gamma$ & & & $\mathbf{0}$ & & 0.9 & $\mathbf{0}$ & \\
\hline $10 \gamma$ & & 1.4 & $\begin{array}{l}0 \\
3.2 \\
5.3 \\
6.8\end{array}$ & 1.5 & & 63.8 & \\
\hline $25 \gamma$ & $\begin{array}{r}11.2 \\
5.9\end{array}$ & & $\begin{array}{l}10.3 \\
13.4^{*} \\
36.5^{*} \\
61.5 \\
77.6\end{array}$ & 8.9 & & & . \\
\hline $50 \gamma$ & & $\begin{array}{l}0 \\
0 \\
0 \\
2 \\
9.2\end{array}$ & & & $13^{*}$ & & \\
\hline $100 \gamma$ & & 21 & & & & & \\
\hline $250 \gamma$ & & & $61.7 *$ & & & & \\
\hline
\end{tabular}

* Patient given steroid therapy. 


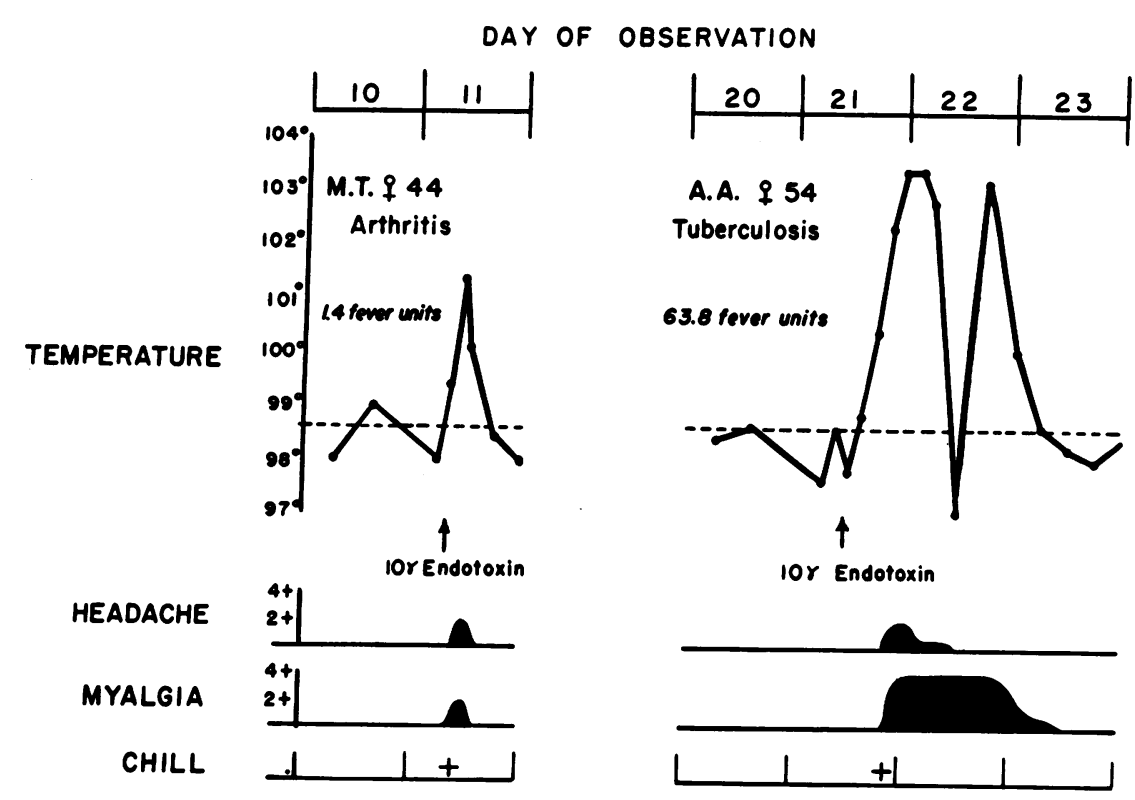

Fig. 4. Effect of Dermal Hypersensitivity on Reaction to Endotoxin

mone $(\mathrm{ACTH})$ in conjunction with challenge with endotoxin. The effects on the responses to endotoxin are summarized in Table XII.

In Patient F. S., the intravenous injection of 100 $\mathrm{mg}$. of hydrocortisone over a six hour period prevented any adverse reaction to challenge with $25 \gamma$ endotoxin, a dose which was toxic for this subject, as demonstrated by a distinct febrile and systemic response when given two days later without hydrocortisone. While the similar administration of $100 \mathrm{mg}$. of hydrocortisone did not prevent the appearance of a moderate reaction to $25 \gamma$ endotoxin in Patient D. L., it did delay the onset of the reaction until six hours after completion of therapy with hydrocortisone. In contrast to these two patients, the simultaneous injection of $100 \mathrm{mg}$. of hydrocortisone hemisuccinate with $25 \gamma$ endotoxin did not prevent a marked reaction in Patient L. B. However, when a second injection of $100 \mathrm{mg}$. of hydrocortisone hemisuccinate was given at the height of the response, a prompt fall in fever and a diminution of the systemic response resulted and persisted for 10 hours, after which a secondary relapse occurred.

TABLE XI

Development of tolerance to endotoxin in humans

\begin{tabular}{|c|c|c|c|c|c|c|}
\hline \multirow[b]{2}{*}{ Patient } & \multirow[b]{2}{*}{$\begin{array}{l}\text { Classification } \\
\text { of disease }\end{array}$} & \multicolumn{2}{|c|}{ Initial injection } & \multicolumn{3}{|c|}{ Subsequent injections } \\
\hline & & $\begin{array}{l}\text { Amount of } \\
\text { endotoxin }\end{array}$ & $\begin{array}{l}\text { Fever } \\
\text { units }\end{array}$ & $\begin{array}{c}\text { Time after } \\
\text { initial } \\
\text { dose }\end{array}$ & $\begin{array}{l}\text { Amount of } \\
\text { endotoxin }\end{array}$ & $\begin{array}{l}\text { Fever } \\
\text { units }\end{array}$ \\
\hline J. A. & Active & $1 \gamma$ & 0 & Day 2 & $5 \gamma$ & 0.9 \\
\hline F.S. & Active & $25 \gamma^{*}$ & $\mathbf{0}$ & Day 3 & $25 \gamma$ & 5.9 \\
\hline J. H. & Active & $25 \gamma$ & 11.2 & Day 6 & $25 \gamma$ & 0.7 \\
\hline S. T. & Active & $5 \gamma$ & $\mathbf{0}$ & $\begin{array}{l}\text { Day } 2 \\
\text { Day } 5 \\
\text { Day } 9\end{array}$ & $\begin{array}{l}10 \gamma \\
20 \gamma \\
30 \gamma\end{array}$ & $\begin{array}{r}3.2 \\
10.3 \\
0.2\end{array}$ \\
\hline C. $K$. & Inactive & $10 \gamma$ & 1.5 & $\begin{array}{l}\text { Day } 4 \\
\text { Day } 8\end{array}$ & $\begin{array}{l}25 \gamma \\
40 \gamma\end{array}$ & $\begin{array}{l}8.9 \\
1.4\end{array}$ \\
\hline H. M. & Control & $250 \gamma$ & 10.9 & Day 2 & $250 \gamma$ & 12.3 \\
\hline
\end{tabular}

\footnotetext{
* Given hydrocortisone.
} 
TABLE XII

Effect of adrenocorticotropic hormone and steroid therapy on reaction to endotoxin in human brucellosis

\begin{tabular}{|c|c|c|c|c|c|c|c|c|c|}
\hline \multirow[b]{3}{*}{ Patient. } & \multirow[b]{3}{*}{$\begin{array}{l}\text { Stage of } \\
\text { disease }\end{array}$} & \multicolumn{2}{|c|}{ ACTH or steroid therapy } & \multirow{3}{*}{$\begin{array}{l}\text { Amount } \\
\text { of } \\
\text { endo- } \\
\text { toxin }\end{array}$} & \multicolumn{4}{|c|}{ Reaction to endotoxin } & \multirow[b]{3}{*}{ Effect of therapy } \\
\hline & & \multirow{2}{*}{$\begin{array}{l}\text { Time } \\
\text { (in relation } \\
\text { to endotoxin) }\end{array}$} & \multirow{2}{*}{$\begin{array}{l}\text { Amount } \\
\text { and type } \\
\text { of therapy }\end{array}$} & & \multicolumn{3}{|c|}{ Febrile response } & \multirow[b]{2}{*}{$\begin{array}{l}\text { Systemic } \\
\text { response }\end{array}$} & \\
\hline & & & & & Onset & $\begin{array}{c}\text { Dura- } \\
\text { tion }\end{array}$ & $\begin{array}{l}\text { Fever } \\
\text { units }\end{array}$ & & \\
\hline S. N. & Healed & 8 hrs. after & $\begin{array}{l}15 \text { U (units) } \\
\text { ACTH I.V. }\end{array}$ & $250 \gamma$ & $0.5 \mathrm{hr}$. & $42 \mathrm{hrs}$. & 61.7 & Marked & $\begin{array}{l}\text { Fall in fever by } 6 \text { hrs. ; } \\
\text { recurrence } 12 \text { hrs. later. }\end{array}$ \\
\hline J. R. & Acute & 14 hrs. after & $\begin{array}{l}20 \text { U (units) } \\
\text { ACTH I.V. }\end{array}$ & $50 \gamma$ & 2 hrs. & $33 \mathrm{hrs}$. & 13 & Marked & $\begin{array}{l}\text { Afebrile and asympto- } \\
\text { matic by } 3 \mathrm{hrs} \text {; recur- } \\
\text { rence after } 12 \mathrm{hrs} \text {. }\end{array}$ \\
\hline \multirow[t]{2}{*}{ F. S. } & $\begin{array}{l}\text { Acute } \\
\text { Day } 1\end{array}$ & Simultaneous & $\begin{array}{l}100 \mathrm{mg} . \\
\text { hydrocor- } \\
\text { tisone I.V. }\end{array}$ & $25 \gamma$ & & & 0 & Minimal & $\begin{array}{l}\text { Excellent suppression } \\
\text { of reaction. }\end{array}$ \\
\hline & Day 3 & & None & $25 \gamma$ & 2 hrs. & 15 hrs. & 5.9 & Moderate & \\
\hline D. L. & Subacute & Simultaneous & $\begin{array}{l}100 \mathrm{mg} . \\
\text { hydrocor- } \\
\text { tisone I.V. }\end{array}$ & $25 \gamma$ & $12 \mathrm{hrs}$. & $10 \mathrm{hrs}$. & 13.4 & Moderate & $\begin{array}{l}\text { Probable delay in onset } \\
\text { of reaction; weaker sys- } \\
\text { temic response. }\end{array}$ \\
\hline L. D. & Healed & $\begin{array}{l}\text { Simultaneous } \\
\text { and } \\
8 \mathrm{hrs} \text {. later }\end{array}$ & $\begin{array}{l}100 \mathrm{mg} . \\
\text { hydrocor- } \\
\text { tisone I.V. } \\
\quad \times 2\end{array}$ & $25 \gamma$ & $7 \mathrm{hrs}$. & $30 \mathrm{hrs}$. & 36.5 & Marked & $\begin{array}{l}\text { ? delay in onset; fall in } \\
\text { fever by } 4 \text { hrs. after } 2 \text { nd } \\
\text { dose, recurrence at } 10 \\
\text { hrs. }\end{array}$ \\
\hline
\end{tabular}

ACTH was administered to two individuals in an attempt to alleviate severe responses to endotoxin. When $20 \mathrm{mg}$. of ACTH was given over a six hour period to Patient J. R., suffering a marked toxic reaction to $50 \gamma$ endotoxin, a dramatic decline in fever and toxemia resulted, so that within three hours the patient was asymptomatic. However, 12 hours later fever and myalgia of moderate intensity recurred, then subsided spontaneously. The response of Patient S. N. was less clear-cut. During a severe reaction to the relatively large dose of $250 \gamma$ endotoxin, $15 \mathrm{mg}$. of ACTH was injected over a three hour interval. The temperature fell slowly over the next six hours and remained normal for 12 hours; the fever and systemic response then recurred and persisted an additional 36 hours.

Immunologic response to endotoxin. Whenever possible, serum precipitins for endotoxin and agglutinins for intact brucella cells were tested both before and after injection of endotoxin. Since the majority of patients were seen only during hospitalization, systematic testing at intervals was not feasible. The results, therefore, do not represent a maximal immunologic response. In 12 patients with negative precipitin reactions prior to receiving endotoxin, 7 gave positive re- actions when tested at later dates. Similarly, 9 of 10 patients with initial absent or low $(1: 80$ or less) agglutinin titers developed significant titers $(1: 320$ to $1: 5,120)$ subsequently. The data were insufficient to permit any detailed conclusions regarding either time of appearance or duration of these antibodies, but in one individual they developed within one week and persisted as long as two years.

\section{DISCUSSION}

The reactions of humans to brucella endotoxin have not been studied in this fashion previously. Pirosky and Molinelli (17) used a Boivin-type of endotoxin extracted from Brucella suis as a skintest antigen in studying individuals from the littoral region of Argentina, an endemic area for brucellosis. They found that those individuals with active brucellosis or those recovered from active disease ( 6 months to 22 years previously) uniformly gave positive reactions of the delayed type, whereas controls showed no reactions. Some of the subjects with positive intradermal reactions also experienced febrile responses to endotoxin.

In their study of the effects of endotoxin upon patients convalescing from typhoid and paratyphoid fevers, Neva and Morgan (14) gave in- 
creasing doses of typhoid and shigella endotoxin over four consecutive days in order to investigate the development of tolerance: Nevertheless, from their data it can be determined that these patients with salmonella infections were more resistant than controls and gave less febrile or systemic reactions to the initial injection of either typhoid or shigella endotoxin. Of interest was the observation that patients with various other infectious diseases all reacted in the same fashion as controls. Heyman and Beeson (18) measured the febrile response to a single injection of dead intact $S$. typhosa cells in patients with a wide variety of diseases; this pyrogenic response most probably represented a reaction to the endotoxin of the cells. Only two convalescent typhoid patients were included but both gave increased febrile responses as compared with controls. The only other subjects demonstrating a consistent increased susceptibility were patients with hepatic cirrhosis. Conversely, resistance to the pyrogenic effect was found in a group of patients undergoing malaria therapy for neurosyphilis. It was speculated that this resistance might be due to a hyperactivity of the reticuloendothelial system in response to the malaria. The observations of Neva and Morgan give somewhat conflicting results from those of Heyman and Beeson as concerns susceptibility to endotoxin in typhoid fever. The increased resistance described by Neva and Morgan contrasts sharply with the susceptibility to endotoxin found in the patients with brucellosis.

The pattern of the febrile responses to brucella endotoxin differed significantly from those previously described in individuals given typhoid and shigella endotoxins (14) or typhoid vaccine (18). With these latter agents, fever uniformly appeared within 30 to 60 minutes and was rarely prolonged beyond six to eight hours. In contrast, with brucella endotoxin there was usually a delay of several hours before fever appeared, and the reaction was sustained more than 10 hours in almost all of the patients. The mechanism of this difference is not apparent. The preparation of brucella endotoxin used was a colloidal suspension; it is conceivable that the delayed reactions reflected simply a difference in physical characteristics of this material from the endotoxins employed by other investigators. On the other hand, it is also possible that the sustained reactions rep- resented a specific reaction of these subjects to brucella endotoxin and therefore differed from the comparatively short-lived nonspecific responses of humans to bacterial endotoxins in general.

While the exact contribution to the symptomatology of brucellosis of this demonstrated sensitivity to brucella endotoxin is conjectural, it is significant that many of the patients with active brucellosis stated that the reaction to brucella endotoxin reproduced almost completely the complaints experienced during the acute phase of their illness. Accordingly, it would appear quite likely that many of the overt manifestations of infection with brucellae could well represent the reaction of the infected host to the endotoxin of the organism, as Morgan has postulated for typhoid fever. The accentuation of susceptibility to endotoxin in individuals who have had active disease and in those with prominent dermal hypersensitivity suggests that this is a manifestation of generalized hypersensitivity to the endotoxin. For further support of such a concept, it would be desirable to determine the reactions of subjects with brucellosis to endotoxins extracted from other microorganisms, since it has been amply demonstrated that all bacterial endotoxins possess similar toxic actions for normal humans. Pending the results of such observations, it is more accurate to employ the term "increased susceptibility" rather than hypersensitivity.

These studies also indicate that exposure of the human host to endotoxin may result in the formation of protective mechanisms against endotoxin. In support of this concept is the demonstration of passive protection for mice against lethal doses of endotoxin with the serum of patients with brucellosis. That this possibly occurs through an immunologic mechanism is suggested by its correlation with serum precipitins and agglutinins. This is in contrast to the lack of correlation between the amount of serum antibodies and the degree of reaction to endotoxin, as also noted by Morgan and Neva $(13,14)$. The capacity of these patients to develop tolerance to endotoxin following one or more injections also represents in effect a protective measure. This tolerance developed in a fashion similar to that described for typhoid endotoxin by Morgan, who found that tolerance appeared after 8 to 10 days of repeated injections. Of particular interest in this 
regard was the observation that resistance to brucella endotoxin developed in one individual following only one injection of endotoxin. In the mouse, evidence of the protective capacity of endotoxin has been obtained (19). Following injections of brucella endotoxin, resistance to endotoxin lethality develops and persists for months. In addition, protection against challenge with viable brucellae is conferred.

The beneficial effect of hydrocortisone or ACTH in ameliorating or preventing the toxicity of brucella endotoxin in humans conforms with the protective action of the adrenocorticosteroids against endotoxin lethality in mice $(10,20)$. It also suggests that the beneficial action of therapy of acute brucellosis with ACTH (21) or steroids (22) may result in part through a suppression of endotoxin activity. In addition, these findings add further evidence to repeated observations that steroid therapy is helpful in the treatment of serious infections due to gram-negative microorganisms (23) in which endotoxin probably contributes to illness.

From these results in humans, coupled with observations in the mouse, the role of endotoxin in the pathogenesis of brucellosis may be envisioned thusly. Upon invasion of the host by brucellae, host defense mechanisms result in disruption of the bacterial cells with liberation of endotoxin. If a sufficient quantity floods the tissues, the host responds with a febrile and systemic response. Such a reaction may occur in any individual provided sufficient endotoxin is liberated. However, it would appear that during infection a state of increased susceptibility develops and renders the host more sensitive to the actions of endotoxin, so that severe reactions may occur with amounts of endotoxin that are harmless to noninfected individuals. While this altered reactivity is significant in the causation of illness in brucellosis, other factors as yet unelucidated may be equally important. In contrast to this undesirable role, endotoxin also has a protective role, as shown by the development of serum antibodies, the development of resistance to endotoxin and the appearance of antibacterial resistance to infection following injections of endotoxin. These conflicting dual roles again emphasize the complexity of host reactions in infectious diseases.

\section{SUMMARY}

1. Sera from patients with brucellosis were found to contain precipitins for brucella endotoxin and to confer passive protection against the lethality of brucella endotoxin for mice.

2. The injection of sufficient quantities of brucella endotoxin into humans caused fever, chills, sweating, myalgia, headache, and malaise. Individuals who had been infected by brucellae were much more susceptible to these effects than noninfected control subjects.

3. The degree of reaction to brucella endotoxin was more severe in those individuals who had experienced active brucellosis (either present or in the past) and in those with more intense intradermal reactions to brucella skin test antigens.

4. Resistance to the toxicity of brucella endotoxin developed after repeated injections of endotoxin.

5. Hydrocortisone or adrenocorticotropic hormone suppressed or ameliorated reactions to brucella endotoxin in five patients.

6. Injections of brucella endotoxin into humans caused the formation of serum precipitins for the endotoxin and serum agglutinins for brucella cells.

7. It is suggested that brucella endotoxin contributes significantly to the pathogenesis of illness in brucellosis, particularly in the infected host who has been made more susceptible to its toxicity.

\section{REFERENCES}

1. Spink, W. W., Braude, A. I., Castaneda, M. R., and Goytia, R. S. Aureomycin therapy in human brucellosis due to Brucella melitensis. J. Amer. med. Ass. 1948, 138, 1145.

2. Miles, A. A., and Pirie, N. W. The properties of antigenic preparations from Brucella melitensis. I. Chemical and physical properties of bacterial fractions. Brit. J. exp. Path. 1939, 20, 83.

3. Lisbonne, H., and Monnier, P. Quelques propriétés de l'antigène complet (Boivin) de Brucella melitensis. C. R. Soc. Biol. (Paris) 1936, 123, 1114.

4. Damboviceanu, A., Barber, C., Pop, A., and Marinov, I. Ontigène complet des brucella. Caractères chimiques. C. R. Soc. Biol. (Paris) 1938, 127, 736.

5. Pennell, R. B. The chemistry of Brucella organisms in Brucellosis. Washington, D. C., American Ass. for the Advancement of Science, 1950, p. 37.

6. Miles, A. A., and Pirie, N. W. The properties of antigenic preparations from Brucella melitensis. 
III. The biological properties of the antigen and the products of gentle hydrolysis. Brit. J. exp. Path. 1939, 20, 278.

7. Paterson, J. S., Pirie, N. W., and Stableforth, A. W. Protective antigens isolated from $\mathrm{Br}$. abortus. Brit. J. exp. Path. 1947, 28, 223.

8. Pop, A., Damboviceanu, A., Barber, C., and Marinov, I. Antigène complet des brucella. Propriétés biologiques. C. R. Soc. Biol. (Paris) 1938, 127, 733.

9. Van Heyningen, W. E. Bacterial Toxins. Oxford, Blackwell Scientific Publications, 1950.

10. Spink, W. W., and Anderson, D. Experimental studies on the significance of endotoxin in the pathogenesis of brucellosis. J. clin. Invest. 1954, 33, 540.

11. Bennett, I. L., Jr., and Beeson, P. B. The properties and biologic effects of bacterial pyrogens. Medicine 1950, 29, 365

12. Thomas, L. The physiological disturbances produced by endotoxins. Ann. Rev. Physiol. 1954, 16, 467.

13. Morgan, $H$. R. Resistance to the action of the endotoxins of enteric bacilli in man. J. clin. Invest. 1948, 27, 706.

14. Neva, F. A., and Morgan, H. R. Tolerance to the action of endotoxins of enteric bacilli in patients convalescent from typhoid and paratyphoid fevers. J. Lab. clin. Med. 1950, 35, 911.

15. Halberg, F., and Spink, W. W. The influence of Brucella somatic antigen (endotoxin) upon the temperature rhythm of intact mice. Lab. Invest. 1956, 5, 283.
16. Benedict, A. A., and Elberg, S. S. Cutaneous hypersensitivity in brucellosis. I. Characterization of an antigen for detection of cutaneous hypersensitivity in brucellosis. J. Immunol. 1953, 70, 152.

17. Pirosky, I., and Molinelli, E. A. Estudios sobre alergia brucelosa. I. Empleo del complejo glucidolipido de Brucella en la investigacion alergica del hombre. Rev. Med. Cienc. afin. (Méx.) 1944, $6,850$.

18. Heyman, A., and Beeson, P. B. Influence of various disease states upon the febrile response to intravenous injection of typhoid bacterial pyrogen. J. Lab. clin. Med. 1949, 34, 1400.

19. Abernathy, R. S. Homologous and heterologous resistance in mice given bacterial endotoxins. J. Immunol. 1957, 78, 387.

20. Halberg, F., Spink, W. W., and Bittner, J. J. Protection by aldosterone and 11,17-oxycorticoids against effects of brucella somatic antigen in adrenalectomized mice. Endocrinology 1956, 59, 380.

21. Spink, W. W., and Hall, W. H. The influence of cortisone and adrenocorticotrophic hormone on brucellosis. II. Adrenocorticotrophic hormone (ACTH) in acute and chronic human brucellosis. J. clin. Invest. 1952, 31, 958.

22. Magill, G. B., Killough, J. H., and Said, S. I. Cortisone and combined antibiotic therapy of acute brucellosis melitensis. Amer. J. Med. 1954, 16, 810.

23. Spink, W. W. Adrenocorticotropic hormone and adrenal steroids in the management of infectious diseases. Ann. intern. Med. 1955, 43, 685. 